\title{
Effect of elevated iron stores on lipid profile in patients of type 2 diabetes mellitus
}

\author{
Amit Kumar Maheshwari', Hardik Javia ${ }^{2,}$, , Dinesh Sharma ${ }^{3}$, Darshan Patel ${ }^{4}$ \\ ${ }^{1,4}$ Assistant Professor, ${ }^{3}$ Tutor, Dept. of Biochemistry, Gujarat Adani Institute of Medical Sciences, Bhuj, Gujarat, ${ }^{2}$ Assistant \\ Professor, Dept. of Biochemistry, C U Shah Medical College, Surendranagar, Gujarat, India
}

\author{
*Corresponding Author: \\ Email: dr_hardikjavia@yahoo.in
}

Received: $28^{\text {th }}$ April, 2018

Accepted: $10^{\text {th }}$ May, 2018

\begin{abstract}
Introduction: Diabetes Mellitus (DM) comprises a group of metabolic disorders presenting with hyperglycemia resulting from insulin deficiency or decreased glucose utilization and increased glucose production. Ferritin is a globular protein which is an index for iron stores present in the body. Many research studies have found relationship between elevated ferritin levels (iron stores) and the development of diabetes mellitus and metabolic syndrome. The present study was done to establish relationship between type 2 diabetes and ferritin levels and to see the effect of elevated iron stores on lipid profile i.e. total cholesterol, triglycerides, HDL (High density lipoprotein) and LDL (low density lipoprotein).

Materials and Methods: 50 cases (patients of type 2 diabetes) and 50 apparently healthy subjects were selected and compared with each other. Serum ferritin, lipid profile i.e. total cholesterol, triglycerides, HDL and LDL were measured from serum at clinical biochemistry section.

Results: Serum ferritin was high $(\mathrm{p}<0.0001)$ in the case group and the correlation between serum ferritin, total cholesterol and triglyceride was positive. However, ferritin levels did not show any significant correlation with other lipid parameters like HDL and LDL.

Conclusion: Study shows elevated ferritin level was found in the patients suffering from type 2 diabetes mellitus. Elevated iron stores are also associated with Total Cholesterol and Triglycerides.
\end{abstract}

Keywords: Type 2 diabetes mellitus, Elevated iron stores, Ferritin, Lipid profile.

\section{Introduction}

Diabetes mellitus is a group of metabolic diseases characterized by hyperglycemia resulting from defects in insulin secretion, insulin action, or both. ${ }^{1}$ Ferritin is a globular protein that stores iron. In deficiency state the iron is released from ferritin. ${ }^{2}$

Iron converts poorly reactive free radical into highly active free radical which can attack cell membrane lipids, DNA, tissues and proteins ${ }^{3}$ which may help in the development of diabetes by developing insulin resistance (hyperinsulinemia) initially followed by decrease secretion and diabetes. ${ }^{4}$

Uncontrolled diabetes causes increased glycation of hemoglobin, which releases the iron from the heme. This leads to continous chain reaction of hyperglycemia, glycation of globin chain of $\mathrm{Hb}$ and elevation in free iron. Free iron starts lipid and protein oxidation and helps in the synthesis of reactive oxygen species. $^{5}$

Iron stores are associated with insulin sensitivity, insulin secretion and type 2 diabetes. Although the exact mechanism of iron-induced diabetes is uncertain, it is likely as discussed below to be mediated by three key mechanisms. ${ }^{6}$

1. Insulin deficiency,

2. Insulin resistance, and

3. Hepatic dysfunction.

Iron stores, expressed as serum ferritin concentration have been proposed to be a component of the insulin-resistance syndrome. Indeed, the concentration of circulating ferritin was significantly associated with centrally distributed body fatness as well as with several other measurements of obesity. ${ }^{7}$

Ferna'ndez et al. described a proportional relationship between serum ferritin and components of the insulin resistance syndrome i.e. serum glucose concentration, diastolic blood pressure, HDL cholesterol, and insulin resistance. ${ }^{8}$

Study conducted by Megan Jehn et al. showed that ferritin levels correlated with serum triglycerides and plasma glucose, as well as markers of insulin resistance. $^{9}$

The present study was done to see the correlation between elevated iron stores reflected by high serum ferritin on total cholesterol, triglycerides, HDL (High Density Lipoprotein and LDL (Low Density Lipoprotein) which will help to understand the effect of iron on the development of metabolic syndrome in type 2 diabetes.

\section{Materials and Methods}

In the present study 50 known cases of Type 2 Diabetes Mellitus attending diabetic clinic of medicine department at Sir Takhtsinhji General Hospital, Bhavnagar and 50 apparently healthy subjects as a control group were selected randomly based on the exclusion and inclusion criteria. Sample size was decided after taking consultation from Statistician from Community Medicine Department, Govt. Medical College, Bhavnagar and it is statistically significant. 
After taking informed consent they all were diagnosed by clinical examination and further evaluated by biochemical investigations. The patients were diagnosed based on the criteria laid down by American Diabetic Association (ADA); 2012.The study was reviewed and approved by the Human Ethics Committee of Govt. Medical College, Bhavnagar.

\section{The Routine follow up of all the cases are as follows}

1. Detailed history including symptomatology, past history, personal history and family history was taken.

2. General examination was carried out with systemic examination.

\section{Inclusion Criteria:}

1. Patient age more than or equal to 35 years, both male and female included.

2. Patient with confirmed case of type 2 diabetes more than 5 years.

3. Patient who is able to give informed concent.

\section{Exclusion Criteria:}

1. Patient having $\mathrm{H} / \mathrm{O}$ anaemia $(\mathrm{Hb}<12 \mathrm{gm} \%)$

2. Patient having $\mathrm{H} / \mathrm{O}$ acute or chronic liver disease

3. Patient having $\mathrm{H} / \mathrm{O}$ inflammatory disease

4. Pregnant women

5. Recent blood donation or transfusion

6. Recent iron therapy

7. Intake of lipid lowering agents

All will be excluded on the basis of their clinical history and Lab. Reports

To find out the effect of body iron stores on lipid profile various cases and subjects underwent the following investigations: Serum Ferritin (SF) levels, lipid profile which includes S. Cholesterol, Triglycerides, HDL (High Density Lipoprotein) and LDL (Low Density Lipoprotein).

Fasting blood samples were collected and analyzed on fully auto analyzer MIURA (Logotech) \& IL-650 (Instrumentation Laboratory, Italy) at National Accreditation board of testing and calibrating laboratories (NABL) accreditated Clinical Biochemistry Section, Laboratory services Sir T Hospital, Bhavnagar.

Estimation of ferritin was done by latex turbidimetry from spinreact, total cholesterol by CHOD PAP, Triglycerides by GPO PAP, HDL and LDL by direct method from instrumentation laboratory (I-LAB).

Internal quality control and external quality control for Serum Ferritin (SF) levels, lipid profile which includes S. Cholesterol, Triglycerides, HDL (High Density Lipoprotein) and LDL (Low Density Lipoprotein) were within the range and calibration was up to date.

In data analysis, comparison between healthy subjects and case group was carried out by applying unpaired t-test and correlation of ferritin with parameters of lipid profile were also studied by applying Pearson correlation test.

\section{Results}

Table 1 shows the comparison of parameters of lipid profile and ferritin in study and control group. As per Table 1 total cholesterol, triglycerides and ferritin are significantly higher $(p<0.0001)$ in the cases compared to the controls while LDL is significant $(\mathrm{p}<$ 0.05 ) and HDL is not significant ( $p>0.05)$.

Table 1: Comparison of biochemical parameters between case $\&$ healthy subjects

\begin{tabular}{|c|c|c|c|c|c|c|c|c|}
\hline \multirow[t]{2}{*}{ Parameter } & \multirow{2}{*}{$\begin{array}{c}\text { Biological } \\
\text { Reference } \\
\text { Interval } \\
\end{array}$} & \multicolumn{3}{|c|}{ Case } & \multicolumn{3}{|c|}{ Healthy Subjects } & \multirow[t]{2}{*}{ Significance } \\
\hline & & Min. & Max. & $\begin{array}{c}\text { Mean } \pm \\
\text { SD }\end{array}$ & Min. & Max. & $\begin{array}{c}\text { Mean } \pm \\
\text { SD }\end{array}$ & \\
\hline $\begin{array}{l}\text { Total } \\
\text { Cholesterol }\end{array}$ & $120-200 \mathrm{mg} / \mathrm{dl}$ & 127.0 & 293.0 & $\begin{array}{c}227.8 \pm \\
39.97\end{array}$ & 107.0 & 302.0 & $\begin{array}{c}173.4 \pm \\
38.94\end{array}$ & $\begin{array}{c}\mathrm{t}=6.896 \\
* * \mathrm{p}<0.0001\end{array}$ \\
\hline Triglycerides & $40-150 \mathrm{mg} / \mathrm{dl}$ & 59.0 & 367.0 & $\begin{array}{c}182.6 \pm \\
49.58\end{array}$ & 58.0 & 219.0 & $\begin{array}{c}122.3 \pm \\
34.82\end{array}$ & $\begin{array}{c}\mathrm{t}=7.045 \\
* * \mathrm{p}<0.0001\end{array}$ \\
\hline HDL & $30-50 \mathrm{mg} / \mathrm{dl}$ & 21.0 & 133.0 & $\begin{array}{c}52.28 \pm \\
19.50\end{array}$ & 32.0 & 104.0 & $\begin{array}{c}50.08 \pm \\
14.41\end{array}$ & $\begin{array}{l}\mathrm{t}=0.3790 \\
\# \mathrm{p} \geq 0.05\end{array}$ \\
\hline LDL & $66-100 \mathrm{mg} / \mathrm{dl}$ & 34.0 & 175.0 & $\begin{array}{c}108.1 \pm \\
34.16\end{array}$ & 47.0 & 195.0 & $\begin{array}{c}89.30 \pm \\
33.46\end{array}$ & $\begin{array}{l}\mathrm{t}=2.786 \\
* \mathrm{p}<0.05\end{array}$ \\
\hline Ferritin & $\begin{array}{c}\mathrm{M}- \\
30-220 \mathrm{ng} / \mathrm{ml} \\
\mathrm{F}-20-110 \\
\mathrm{ng} / \mathrm{ml}\end{array}$ & 20.0 & 716.0 & $\begin{array}{c}319.7 \pm \\
133.6\end{array}$ & 23.0 & 134.0 & $\begin{array}{l}67.40 \pm \\
30.53\end{array}$ & $\begin{array}{c}\mathrm{t}=13.02 \\
* * \mathrm{p}<0.0001\end{array}$ \\
\hline
\end{tabular}

Note: $* \mathrm{p}<0.05$ - significant

$* * p<0.001-$ highly significant

$\# \mathrm{p} \geq 0.05$ - not significant 
Table 2: Correlation of serum ferritin with parameters of lipid profile in case Group

\begin{tabular}{|l|c|c|c|c|}
\hline \multicolumn{2}{|c|}{$\begin{array}{c}\text { Ferritin }\left(\mathbf{3 1 9 . 7} \begin{array}{c}\mathbf{\pm 1 3 3 . 6} \text { ) compared to other } \\
\text { parameter }\end{array}\right. \\
\text { Name of parameter }\end{array}$} & $\begin{array}{c}\text { Two tailed pean value } \\
\text { value }\end{array}$ & $\begin{array}{c}\text { Pearson coefficient } \\
(\mathbf{r})\end{array}$ & Significance \\
\hline Total Cholesterol & $227.8 \pm 39.97$ & $\mathrm{P}<0.0001$ & 0.604 & Yes \\
\hline Triglyceride & $182.6 \pm 49.58$ & $\mathrm{P}<0.0001$ & 0.600 & Yes \\
\hline HDL & $52.28 \pm 19.50$ & $\mathrm{P}=0.9327$ & 0.012 & No \\
\hline LDL & $108.1 \pm 34.16$ & $\mathrm{P}=0.5148$ & 0.094 & No \\
\hline
\end{tabular}

Table 2 shows that levels of serum ferritin were positively correlated with values of total cholesterol $(\mathrm{r}=0.604$, $\mathrm{p}<0.0001)$, triglycerides $(\mathrm{r}=0.600, \mathrm{p}<0.0001)$, while the values of HDL $(\mathrm{r}=0.012, \mathrm{p}=0.9327)$ and LDL $(\mathrm{r}=0.094$, $\mathrm{p}=0.5148$ are not positively correlated with elevated ferritin.

\section{Discussion}

From the results it is obvious that increased body iron stores reflected by serum ferritin levels had a statistically significant correlation with total cholesterol and triglycerides.

Type 2 diabetes is a multi-causal disease which commences slowly with insulin resistance and develops into the glucose intolerance. Systemically these alterations are accompanied with changes in a variety of biochemical processes such as elevated iron stores, obesity and an altered lipid profile. ${ }^{10}$

Ferritin is the principal storage protein for iron in tissues and is involved in its uptake, accumulation and release in cells. ${ }^{11}$

Because iron participates in the formation of reactive oxygen species, organisms take great care in the handling of iron. Indeed, iron sequestration in transport and storage proteins may contribute to antioxidant defenses. It is now well established that oxidants can cause the release of catalytic iron, thus, a vicious cycle is initiated that leads to the formation of more reactive oxygen species. ${ }^{6}$

Recently, a link has been established between increased dietary iron intake particularly eating red meat and increased body iron stores and the development of diabetes. A causative link with iron overload is suggested by the improvement in insulin sensitivity and insulin secretion with frequent blood donation and decreased iron stores. ${ }^{12}$

Frequent blood donation lead to decrease iron stores which in turn reduces post-prandial hyperinsulinemia in healthy volunteers and improves insulin sensitivity. ${ }^{13}$

In the present study, ferritin levels were significantly higher in case group as compared to controls (Table 1) which were consistent with the reports published by Mahmoud M.A Yossof et al. which included 50 patients of type $2 \mathrm{DM}$, the concentrations of Ferritin were significantly higher in the case group than in the control subjects. ${ }^{14}$

In present study, ferritin levels were positively correlated with total cholesterol $(\mathrm{r}=0.60, \mathrm{p}<0.0001)$, Triglycerides $(r=0.600, p<0.0001)$. However, ferritin levels did not show any significant correlation with other lipid parameters like HDL and LDL (Table 2) which is parallel with the study conducted by Sumeet
Smotra and colleagues in 50 patients of type $2 \mathrm{DM}$ patients found increased levels of serum ferritin, total cholesterol and triglyceride. ${ }^{15}$

Megan Jehn et al. in 2004 found that elevated iron stores were positively associated with the prevalence of the diabetes, metabolic syndrome and with insulin resistance. $^{7}$

F. Sharifi ES et al. found association between elevated level of serum ferritin, total cholesterol and triglycerides. ${ }^{16}$

\section{Conclusion}

In conclusion, ferritin is higher in case group as compared to healthy subjects. Ferritin levels also correlated with individual components of the metabolic syndrome, particularly total cholesterol and serum triglycerides. We conclude that more studies should be carried out to see the role of elevated iron stores reflected by ferritin levels on patho-physiology of diabetes as well as metabolic syndrome.

\section{References}

1. Kasper D. Harrison's Principles of Internal Medicine. $16^{\text {th }}$ Edition. USA. McGraw Hill. 2005. Pp. 2152-80.

2. Casiday R, Frey R. Iron Use and Storage in the Body: Ferritin and Molecular Representations. Washington Univercity. 2000.

Availablefrom:http://www.chemistry.wustl.edu/ edudev/ LabTutorials/Ferritin/Ferritin.html

3. R Jiang, E JoAnn, B James, J Ma, N Rifai, B Frank. Body Iron Stores in Relation to Risk of Type 2 diabetes in apparently healthy women. JAMA $2004 \mathrm{Feb}$; 291(6):71117.

4. S Smotra, V. Tandon, S Sharma, R. Kudyar. Serum Ferritin and Type-2 Diabetes Mellitus. JK Science. 2007 October-December; vol. 9 (4):164-66.

5. J Shetty, M Prakash, M Ibrahim. Relationship Between Free Iron And Glycated Hemoglobin In Uncontrolled Type 2 Diabetes Patients Associated With Complications. IJCB. 2008;23(1):67-70. doi:10.1007/s12291-008-0016-4

6. S Swaminathan, A Vivian, Fonseca, G Muhammad, S Shah. The Role of Iron in Diabetes and Its Complications. Diabete Care 2007 July;30(7):1926-33.

7. R Gillum. Association of serum ferritin and indices of body fat. International Journal of Obesity. 2001;25:63945

8. J Ferna 'ndez-Real, P Georgina, A Castro, F Garci'aBragado, I Herna'ndez-Aguado, W Ricart. Blood Letting in High-Ferritin Type 2 Diabetes. Diabetes. 2002 April;51:1000-04. 
9. M Jehn, J Clark, E Guallar. Serum Ferritin and Risk of the Metabolic Syndrome in U.S. Adults. Diabetes Care 2004 October;27(10):2422-28.

10. NH Al-Rawi. Oxidative stress, antioxidant status and lipid profile in the saliva of type 2 diabetics. Diab Vasc Dis Res. 2011;8(1):22-28. doi:

$10.1177 / 1479164110390243$.

11. E Ashley. Ferritin. Association for Clinical Biochemistry 2012:1-8

12. R Jiang, J Ma, A Ascherio, M Stampfer, W Willett, F Hu. Dietary iron intake and blood donations in relation to risk of type 2 diabetes. AJCN. 2004;79:70-5.

13. K Dmochowski, D Finegood, W Francombe, B Tyler, B Zinman. Factors determining glucose tolerance in patients with thalassemia major. JCEM. Aug-93.77(2):478-83.

14. M Yossof, E El-Khalek, M El-Halim E Helaly, S ElAzhary, F El-Shahat, S. Abd El-Gawad. Ferritin levels in chronic hepatitis $\mathrm{C}$ virus infection with and without Diabetes. El-Azhar University. 2002.
15. Sumeet Smotra, R.P Kudyar. Relationship between Serum Ferritin and Type-2 Diabetes Mellitus. JK Science. October-December 2008;10(4):170-74.

16. F. Sharifi, S. Sazandeh. Serum Ferritin in Type 2 Diabetes Mellitus and Its Relationship with Hba1c. Acta Medica Iranica. 2004;42(No.2):142-45.

How to cite this article: Maheshwari A K, Javia H, Sharma D, Patel D. Effect of elevated iron stores on lipid profile in patients of type 2 diabetes mellitus. Int $\mathbf{J}$ Clin Biochem Res. 2018;5(3):493-496. 